\title{
Pelaksanaan Student Centered Learning Berbasis Online pada Pembelajaran Sosiologi Siswa Kelas X IPS SMA Negeri 4 Bukittinggi Masa Pandemi Covid-19
}

\author{
Rahmah Fitriyani ${ }^{1}$, Reno Fernandes ${ }^{2}$ \\ ${ }^{1,2}$ Universitas Negeri Padang \\ Email: rahmahfitriyani001@gmail.com, renofernandes@fis.unp.ac.id
}

\begin{abstract}
Abstrak
Penelitian ini dilatar belakangi oleh perubahan yang terjadi pada proses pembelajaran karena pandemi Covid-19. Perubahan yang terjadi adalah pembelajaran dilakukan secara online. Meskipun dilakukan secara online pembelajaran tetap berbasis Student Centered Learning. Penelitian ini bertujuan untuk mendeskripsikan (1) pelaksanaan Student Centered Learning berbasis online pada pembelajaran sosiologi siswa kelas X IPS SMA Negeri 4 Bukittinggi masa pandemi Covid-19, (2) kendala-kendala yang dalam pelaksanaan Student Centered Learning berbasis online pada pembelajaran sosiologi siswa kelas X IPS SMA Negeri 4 Bukittinggi masa pandemi Covid-19. Metode penelitian yang digunakan adalah kualitatif dengan tipe studi kasus. Teknik pengumpulan data yang digunakan adalah observasi, wawancara dan studi dokumentasi. Hasil penelitian ini menunjukan bahwa (1) pelaksanaan Student Centered Learning berbasis online pada pembelajaran sosiologi siswa kelas X IPS SMA Negeri 4 Bukittinggi masa pandemi Covid-19 sudah terlaksana sesuai tuntutan pembelajaran kurikulum 2013 yang berbasis Student Centered Learning dan sesuai protokoler Home Learning, (2) terdapat kendala-kendala yang dialami guru dan siswa karena belum sepenuhnya bisa beradaptasi dengan proses pembelajaran online.
\end{abstract}

Kata kunci: Covid-19, Pembelajaran Online, Student Centered Learning.

Abstract
This research is motivated by changes that have occurred in the learning process due to the Covid-19 pandemic. The change that occurs is that learning is done online. Even though it is done online, the learning is still based on Student Centered Learning. This research aims to describe (1) the implementation of online-based student centered learning on sociology learning in class X IPS students of SMA Negeri 4 Bukittinggi during the Covid-19 pandemic, (2) the constraints in implementing online-based student centered learning in the sociology learning of classroom students $X$ IPS SMA Negeri 4 Bukittinggi during the Covid-19 pandemic. The research method used is qualitative with the type of case study. Data collection techniques used were observation, interviews and documentation study. The results of this study indicate that (1) the implementation of online-based student centered learning on sociology learning in class $X$ IPS of SMA Negeri 4 Bukittinggi during the Covid-19 pandemic period has been carried out according to the demands of 2013 curriculum learning based on student centered learning and according to the Home Learning protocol, (2) there are obstacles experienced by teachers and students because they have not been able to fully adapt to the online learning process.

Keywords: Covid-19, Online Learning, Student Centered Learning.

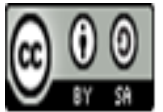

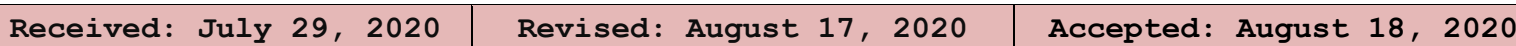




\section{Pendahuluan}

Pendidikan merupakan alat yang paling penting bagi suatu bangsa untuk mencari jati diri dan meningkat daya saing (Fernandes, 2017). Berdasarkan Undang-undang No. 20 Tahun 2003 tentang Sistem Pendidikan Nasional, Pendidikan adalah usaha sadar dan terencana untuk mewujudkan suasana belajar dan proses pembelajaran agar peserta didik secara aktif mengembangkan potensi dirinya untuk memiliki kekuatan spiritual, keagamaan, pengendalian diri, kepribadian, kecerdasan, akhlak mulia, serta keterampilan yang diperlukan dirinya, masyarakat, bangsa dan negara (Depdiknas, 2003).Menurut Bharvard (dalam Clorawati et al., 2017) dalam pelaksanaannya banyak komponen pendidikan yang harus diperbaiki seperti kurikulum. Kurikulum nasional yang digunakan dalam pembelajaran saat ini adalah kurikulum 2013, kurikulum ini telah memberi arahan yang jelas bahwa siswa wajib memiliki pengalaman belajar dengan memberikan penekan perlunya penyelidikan ilmiah (inquiy) agar siswa mampu melakukan sinkronisasi antara materi yang dipelajari dan realita yang ada disekitarnya (authentic), dengan harapan siswa mampu mengkonstruksi konsep serta melatih kemampuan metakognitifnya (Sylvia et al., 2019). Sehingga siswa memiliki keterampilan yang dibutuhkan di abad ke-21.

Menurut Zubaidah ( dalam Mutmainah \& Pratiwi, 2019), keterampilan abad 21, yaitu learning to know, learning to do, learning to be dan learning to live together. Tuntutan-tuntutan yang serba baru tersebut meminta berbagai terobosan dalam berfikir, penyusunan konsep dan tindakan-tindakan (Wijaya et al., 2016). Dalam hal ini, pembelajaran abad 21 menuntut sumber daya manusia yang handal, terampil dalam akademik, terampil hidup bersosialisasi dengan teknologi komunikasi yang tersedia di sekitarnya (Prasetyo, 2017).

Prinsip pokok pembelajaran abad 21 terdiri atas 4, yaitu Instruction Should be StudentCentered, Education Should be Collaborative, Learning Should Have Context, dan Schools Should be Integrated with Society (Syahputra, 2018). Selain itu pendidikan abad 21 juga menekankan adanya keterampilan 4C yang berorientasi pada HOTS (High Order Thingking) yang menekankan kemampuan berfikir tingkat tinggi (Putra \& Nurlizawati, 2019). Saat ini permasalahan yang serius dihadapi oleh dunia pendidikan global khususnya Indonesia saat ini yaitu mewabahnya suatu penyakit yang disebabkan oleh virus corona atau yang lebih dikenal dengan COVID-19 (Corona Virus Diseases-19).

Covid-19 merupakan akronim dari coronavirus disease-2019. Coronavirus merupakan keluarga besar virus yang menyebabkan penyakit ringan sampai berat pada manusia, seperti common cold atau pilek dan penyakit yang serius seperti MERS dan SARS. Virus korona tipe baru yang menjadi pandemic ini bernama SARS-CoV-2 (severe acute respiratory syndromecoronavirus-2). Virus inilah yang menyebabkan Covid-19 (Adji, 2020). Karakteristik virus ini adalah kecepatan penyebaran yang tinggi. Penyebaran virus Covid-19 ini telah menyebabkan angka kematian paling tinggi di berbagai negara dunia saat ini, sudah banyak korban yang meninggal dunia (Marharjono, 2020). Berdasarkan data WHO diperoleh bahwa Covid-19 telah menjadi pandemi global dengan 9.843.073 orang yang terkonfirmasi positif Covid-19 di 216 negara di seluruh dunia (Update: 30 Juni 2020 pukul 15.10 WIB). Virus corona juga telah mewabah di Indonesia sejak awal Maret hingga saat ini 30 Juni 2020 yang mana terdapat 56.385 orang terkonfirmasi positif COVID-19 dari 34 Provinsi dan 449 Kabupaten/Kota (Gugus Tugas Percepatan Penanganan COVID-19, 2020). Dampak yang ditimbulkan dari pandemi Covid-19 ini telah mengubah berbagai aspek kehidupan manusia.

Sejak mewabahnya pandemi Covid-19 di Indonesia, pemerintah telah mengeluarkan berbagai kebijakan untuk mengurangi tingkat penyebaran virus corona dengan memberlakukan social distancing, physical distancing hingga memberlakukan PSBB (pembatasan sosial berskala besar) pada beberapa daerah. Kebijakan-kebijakan yang dikeluarkan untuk membatasi penyebarah Covid-19 berdampak pada berbagai bidang kehidupan diseluruh dunia khususnya

Jurnal Sikola: Jurnal Kajian Pendidikan dan Pembelajaran Vol. 2, No. 1, Th. 2020 
pendidikan di Indonesia (Herliandry et al., 2020). Dengan adanya pembatasan interaksi, kementerian pendidikan di Indoneisa juga mengeluarkan kebijakan untuk mengurangi penyebaran virus ini. Kebijakan dibidang pendidikan yaitu dikeluarkannya Surat Edaran No 4 Tahun 2020 tentang pelaksanaan kebijakan pendidikan dalam masa darurat penyebaran coronavirus disease (COVID-19) oleh Menteri Pendidikan dan Kebudayaan Republik Indonesia Mas Nadiem Anwar Makarim.

Kebijakan dalam Surat Edaran No 4 Tahun 2020 tentang pelaksanaan kebijakan pendidikan dalam masa darurat penyebaran coronavirus disease (COVID-19) terdapat poin 2 yang menyatakan bahwa proses pembelajaran dilaksanakan dari rumah yang dijelaskan sebagai berikut. Pertama, belajar dari rumah melalui pembelajaran daring/jarak jauh dilaksanakan untuk memberikan pengalaman belajar yang bermakna bagi siswa, tanpa terbebani tuntutan menuntaskan seluruh capaian kurikulum untuk kenaikan kelas maupun kelulusan. Kedua, belajar dari rumah dapat difokuskan pada pendidikan kecakapan hidup antara lain mengenai pandemi Covid-19. Ketiga, aktivitas dan tugas pembelajaran belajar dari rumah dapat bervariasi antarsiswa, sesuai minat dan kondisi masing-masing, termasuk mempertimbangkan kesenjangan akses/fasilitas belajar di rumah. Keempat, bukti atau produk aktivitas belajar dari rumah diberi umpan balik yang bersifat kualitatif dan berguna dari guru, tanpa diharuskan memberi skor/nilai kuantitatif (Kemendikbud RI, 2020).

Berdasarkan Surat Edaran di atas, maka semua guru dan siswa belajar dari rumah serta proses belajar mengajar diganti dari tatap muka ke pembelajaran online guna mencegah penyebaran Covid-19 (Purwanto et al., 2020). Salah satu jenjang pendidikan yang menjadi korban akibat pandemi Covid-19 ini adalah Sekolah Menengah Atas (SMA). Salah satu SMA yang terkena damapak pandemi Covid-19 ini adalah SMA Negeri 4 Bukittinggi. Salah satu mata pelajaran yang sesuai dengan tuntutan kurikulum 2013 adalah mata pelajaran sosiologi.Tujuan pembelajaran sosiologi pada kurikulum 2013 adalah meningkatkan penguasaan pengetahuan sosiologi di kalangan siswa yang berorientasi pada pemecahan masalah dan pemberdayaan sosial (Mutmainah \& Pratiwi, 2019). Disamping itu, sosiologi dalam pembelajaran bertujuan untuk memberikan kompetensi kepada siswa dalam memahami konsep-konsep sosiologi (Soekanto, 2012).

Salah satu pendekatan pembelajaran yang harus digunakan oleh guru dalam mengajar sesuai dengan standar proses kurikulum 2013 adalah student centered learning (SCL) dengan menggunakan model-model pembelajaran yang menunjang keaktifan siswa (Fernandes, 2019). SCL merupakan suatu pendekatan pembelajaran yang menempatkan siswa sebagai subjek belajar dan kegiatan belajar bersifat modern. Pendekatan pembelajaran yang berorientasi pada siswa, manajemen, dan pengelolaannya ditentukan oleh siswa (Rusman, 2014).

\section{Metode Penelitian}

Jenis penelitian ini menggunakan pendekatan kualitatif, karena penelitian ini bertujuan untuk mendeskripsikan tentang pelaksanaan Student Centered Learning Berbasis Online pada Pembelajaran Sosiologi Siswa Kelas X IPS SMA Negeri 4 Bukittinggi Masa Pandemi Covid-19. Penelitian kualitatif adalah penelitian yang ditujukan untuk mendeskripsikan dan menganalisis fenomena, peristiwa, aktivitas sosial, sikap, kepercayaan, persepsi, pemikiran orang secara individu maupun kelompok (Sukmadinata \& Nana Syaodih, 2007). Tipe penelitian ini adalah studi kasus, data diperoleh dengan cara memahami individu yang dilakukan secara integrative dan komprehensif agar diperoleh pemahaman yang mendalam tentang individu tersebut beserta masalah yang dihadapinya dengan tujuan masalahnya dapat terselesaikan dan memperoleh perkembangan diri yang baik (Rahardjo et al., 2011). Sehingga diperoleh gambaran yang menyeluruh dan mendalam tentang bagaimana pelaksanaan Student Centered Learning berbasis 
online pada pembelajaran sosiologi siswa kelas X IPS SMA Negeri 4 Bukittingi masa pandemi Covid-19.

Lokasi penelitian di SMA Negeri 4 Bukittinggi karena SMA Negeri 4 Bukittinggi telah menerapkan kurikulum 2013 dalam proses pembelajaran dan telah melaksanakan proses pembelajaran secara online selama pandemi Covid-19. Pemilihan informan dalam penelitian ini dilakukan melalui teknik purposive sampling. Teknik ini dipilih dengan pertimbangan bahwa peneliti telah memiliki gambaran terhadap orang-orang yang akan dijadikan informan dalam penelitian ini. Informan dalam penelitian ini adalah guru mata pelajaran sosiologi kelas X IPS dan siswa kelas X IPS SMA Negeri 4 Bukittinggi.

Teknik pengumpulan data yang digunakan dalam penelitian ini adalah observasi, wawancara mendalam dan dokumentasi. Observasi yang dilakukan dalam penelitian ini adalah observasi non partisipan, dimana peneliti tidak terlibat langsung dalam kegiatan yang dilakukan oleh informan. Setelah melakukan observasi peneliti melakukan \wawancara mendalam dengan informan. Selain itu peneliti juga melakukan studi dokumentasi guna untuk memberikan kelengkapan data yang dapat menunjang keberhasilan penelitian ini.

Penelitian ini menggunakan analisis data dari model Miles dan Hubberman (Yusuf, 2014) yang terdiri dari tiga langkah, yaitu (1) reduksi data, (2) penyajian data, (3) penarikan kesimpulan. Dalam reduksi data, peneliti mempertajam, memilih, memfokuskan, membuang, dan mengorganisasikan data mengenai pelaksanaan Student Centered Learning berbasis online pada pembelajaran sosiologi siswa kelas X IPS SMA Negeri 4 Bukittingi masa pandemi Covid-19. Kemudian dalam penyajian data, peneliti menyajikan data secara sederhana sehingga mempermudah dalam penarikan kesimpulan. Selanjutnya pada penarikan kesimpulan, peneliti mengumpulkan dat-data hasil wawancara dan observasi mengenai pelaksanaan Student Centered Learning berbasis online pada pembelajaran sosiologi siswa kelas X IPS SMA Negeri 4 Bukittingi masa pandemi Covid-19.

\section{Hasil dan Pembahasan}

\section{Pelaksanaan Student Centered Learning Berbasis Online}

Pada tahun ajaran 2016/2017 Kepala Sekolah SMA Negeri 4 Bukittinggi yaitu Bapak Drs. H. Firdaus, M.Pd mengeluarkan kebijakan untuk menerapkan kurikulum 2013 dalam proses pembelajaran. Berdasarkan kebijakan tersebut, sejak tahun 2016 proses pembelajaran dirubah dari pembelajaran yang berpusat pada guru (teacher centered learning) ke pembelajaran yang berpusat pada siswa atau (student centered learning). Pada kurikulum 2013 ini siswa lebih dituntut aktif, kreatif, inovatif dan mandiri dalam proses pembelajaran. Oleh sebab itu, sejak tahun ajaran 2016/2017 sampai sekarang SMA Negeri 4 Bukittingi sudah menerapkan pembelajaran kurikulum 2013 berbasis Student Centered Learning.

Sejak Covid-19 mulai mewabah di Indonesia termasuk kota Bukittinggi, sekolah-sekolah di Bukittinggi mulai melakukan proses pembelajaran secara daring (online). Berdasarkan wawancara yang peneliti lakukan dengan Bapak Afis Al Hadi, S.Hum selaku wakil kurikulum SMA Negeri 4 Bukittinggni, beliau mengatakan bahwa ketika terjadi penyebaran wabah Covid19 di Indonesia kepala sekolah dan Kepala Dinas Pendidikan kota Bukittinggi serta Kepala Cabang Dinas Pendidikan Wilayah 1 Sumatera Barat langsung melakukan rapat tanggal 17 Maret 2020, yang mana salah satu hasil rapat tersebut adalah diliburkannya seluruh jenjang pendidikan dan proses belajar mengajar dialihkan dari tatap muka ke pembelajaran online. Menindaklanjuti hasil rapat tersebut, tanggal 18 Maret 2020 kepala sekolah SMA Negeri 4 Bukittinggi, yaitu Ibuk Dra. Hj. Eli Noverman, M.Si mengeluarkan kebijakan guna mencegah penyebaran wabah Covid-19 dilingkungan sekolah. Salah satu isi kebijakan tersebut adalah guru dan siswa mulai melaksanakan proses pembelajaran secara daring maupun luring tanggal 23 Maret 2020 melalui aplikasi WhatsApp, Google Classroom, Email, Telegram, Link Web yang disediakan oleh sekolah dan media yang digunakan tergantung masing-masing guru yang

Jurnal Sikola: Jurnal Kajian Pendidikan dan Pembelajaran Vol. 2, No. 1, Th. 2020 
bersangkutan. Berdasarkan hasil wawancara, peneliti memperoleh infomasi bahwa proses pembelajaran daring sosiologi kelas X IPS dilaksanakan melalui WhatsApp group dengan menggunakan alat berupa handphone dan fasilitas internet.

Sedangkan saat pembelajaran luring alat yang digunakan adalah buku, alat tulis, buku cetak sosiologi serta bahan ajar sosiologi. Kemudian proses pembelajaran yang dilakukan berpedoman pada hasil rapat majelis guru. Meskipun pembelajaran dilaksanakan secara daring maupun luring, model-model pembelajaran yang digunakan berorientasi Student Centered Learning. Berdasarkan wawancara yang telah peneliti lakukan, peneliti menyimpulkan bahwa Student Centered Learning yang dilaksanakan dalam proses pembelajaran sosiologi kelas X IPS di SMA Negeri 4 Bukittinggi ada dua, yaitu (1) pelaksanaan Student Centered Learning berbasis online learning dengan menggunakan model discovery learning, (2) pelaksanaan student centered learning berbasis online learning dengan sistem penugasan. Adapun penjabarannya sebagai berikut.

\section{Pelaksanaan Student Centered Learning Berbasis Online dengan Menggunakan Discovery learning}

Discovery learning adalah model pembelajaran yang difokuskan pada pemanfaatan informasi yang tersedia, baik yang diberikan guru maupun yang dicari sendiri oleh siswa, untuk membangun pengetahuan dengan cara belajar mandiri. Model ini berbentuk pemberian tugas belajar atau penelitian kepada siswa dengan tujuan supaya siswa dapat mencari sendiri jawabannya tanpa bantuan pengajar. Misalnya dengan memberikan tugas kepada siswa untuk memperoleh bahan ajar dari sumber-sumber yang dapat diperoleh melalui internet atau melalui buku, koran, majalah, dan lain sebagainya (Hosnan, 2014). Dalam pembelajaran daring maupun luring terlihat proses pembelajaran yang dilaksanakan oleh Bapak Mhd Ulil Ikhsan, S.Sos. di kelas X IPS 5 dan 6 adalah discovery learning. Hal ini terlihat dari proses pembelajaran yang dilakukan beliau mengarah pada sintak-sintak model discovery learning.

Berdasarkan wawancara yang peneliti lakukan dengan Bapak Mhd Ulil Ikhsan, S.Sos. (45 tahun), proses pembelajaran daring berlangsung selama 5 minggu di SMA Negeri 4 Bukittinggi. Oleh karena itu, selama 5 minggu itulah beliau melaksanakan student centered learning berbasis online learning. Proses pembelajaran daring yang dilaksanakan oleh Bapak Mhd Ulil Ikhsan, S.Sos. hanya melalui WhatsApp group dengan memanfaatkan alat berupa handphone dan fasilitas internet. Sedangkankan saat pembelajaran luring beliau memberikan tugas kepada siswa dan siswa mengerjakan tugas dengan memanfaatkan alat berupa handphone, buku tulis, alat tulis, bahan ajar, buku cetak sosiologi. Setelah itu beliau melakukan proses pembelajaran sosiologi sesuai dengan jadwal yang lama atau berdasarkan jadwal yang sudah disusun sebelum pandemi Covid-19 mewabah di Indonesia tetapi porsi jam pelajaran dikurangi, yang semula 1 jam pelajaran itu 45 menit maka diperpendek menjadi 1 jam pelajaran 30 menit. Jadwal mengajar Bapak Mhd Ulil Ikhsa, S.Sos yaitu di kelas X IPS 5 beliau melaksanakan proses pembelajaran setiap hari kamis di jam ke 6, jam ke 7, jam ke 8 dan proses pembelajaran di kelas X IPS 6 dilaksanakan setiap hari kamis di jam ke 3, jam ke 4, jam ke 5 . Sedangkan untuk materi pembelajaran beliau berpedoman pada silabus yang sudah disiapkan sebelum pandemi Covid-19 tetapi kompetensi dasar dan indikator-indikator pembelajarannya di permudah yaitu pada minggu pertama materi pembelajaran yang dibahas adalah pengantar penelitian, minggu ke dua instrumen pengumpulan data, minggu ke tiga teknik pengambilan sampel, minggu ke empat jenis-jenis penelitian dan pada minggu ke lima Bapak Mhd Ulil Ikhsan, S. Sos memberikan tugas kepada siswa kelas X IPS 5 dan 6 berupa soal objektif mengenai materi yang sudah dipelajari pada pertemuan sebelumnya.

Pada minggu pertama sampai minggu ke 5 beliau selalu melakukan pendahuluan pembelajaran selama 15 menit. Hal yang dilakukan beliau adalah mengucapkan salam, kemudian beliau menanyakan kabar siswa, beliau juga menjelaskan bagaimana proses penilaian yang dilakukan dan setelah itu beliau meminta siswa mengisi absensi mata pelajaran

Jurnal Sikola: Jurnal Kajian Pendidikan dan Pembelajaran Vol. 2, No. 1, Th. 2020 
sosiologi dan absensi sekolah, setelah itu, beliau menyebutkan kompetensi dasar dan indikatorindikator yang akan didiskusikan dan kemudian beliau mengirimkan materi yang akan didiskusikan pada setiap pertemuan ke WhatsApp group berupa soft copynya. Setelah itu, pada kegiatan inti beliau melaksanakn proses pembelajaran selama 50 menit, hal yang dilakukan beliau, yaitu siswa diberi waktu 10 menit untuk membaca dan memahami materi yang dibahas dalam pertemuan tersebut. Setelah itu, Bapak Mhd Ulil Ikhsan dan siswa melakukan diskusi mengenai pembelajaran yang dibahas pada setiap pertemuan selama 40 menit. Pertama-tama Bapak Mhd Ulil Ikhsan memberikan pertanyan-pertanyaan yang berkaitan dengan pembelajaran yang dibahas kepada siswa. Misalnya pada pertemuan pertama indikator pembelajarannya tentang pengantar penelitian sosial, lalu beliau menanyakan kepada siswa apa itu penelitian sosial. Kemudian siswa mencari jawabannya melalui berbagai sumber yang dimiliki oleh masing-maisng siswa. Setelah siswa menemukan jawabnnya, siswa menuliskan jawabannyaberupa tulisan pada list yang sudah disediakan di WhatsApp group tersebut. Kemudian setelah itu dilanjutkan dengan pertanyaan apa contoh penelitian sosial dan begitu seterusnya sampai pertemuan ke lima. Selama proses diskusi berlangsung, jika ada jawaban siswa yang salah, maka diberikan jawaban yang benar agar siswa paham dengan materi yang sedang didiskusikan. Jika ada siswa yang belum berpartisipasi dalam PBM, disebutkan namanama siswa tersebut agar mereka juga bisa berpartisipasi dalam PBM.

Setelah diskusi selesai, selama 15 menit pada kegiatan penutup Bapak Mhd Ulil Ikhsan, S.Sos menyimpulkan pembelajaran yang telah dilakukan hari itu, kemudian beliau menyebutkan manfaat dari pembelajaran yang sudah didiskusikan hari itu, beliau menyebutkan nama-nama siswa yang aktif selama proses pembelajaran berlangsung dan memberikan tugas berupa resume materi tentang pembelajaran yang sudah didiskusikan maupun latihan berdasarkan apa yang diperintahkan. Tugas tersebut dibuat di buku latihan maupun di buku catatan, lalu tugas tersebut difoto dan dikirim ke WhatsApp pribadi Bapak Mhd Ulil Ikhsan sampai batas waktu yang ditentukan, ada yang dikasih waktu 4 jam dan paling lama tugas dikumpul hari itu samapi jam 12 malam. Setelah itu di akhir pembelajaran disebutkan namanama siswa yang aktif selama proses belajar mengajar sosiologi hari itu.

\section{Pelaksanaan Student Centered Learning Berbasis Online Learning dengan Sistem Penugasan}

Berdasarkan wawancara yang peneliti lakukan dengan Ibuk Dra. Elmawati (56 tahun), diperoleh informasi bahwa proses pembelajaran yang dilakukan Ibuk Dra. Elmawati selama 5 minggu sudah student centered learning. Proses pembelajaran daring yang dilaksanakan oleh Ibuk Dra. Elmawati (56 tahun) hanya melalui WhatsApp group dengan memanfaatkan alat berupa handphone dan fasilitas internet. Sedangkankan saat pembelajaran luring beliau memberikan tugas kepada siswa dan siswa mengerjakan tugas dengan memanfaatkan alat berupa handphone, buku tulis, alat tulis, bahan ajar, buku cetak sosiologi. Setelah itu beliau melakukan proses pembelajaran sosiologi sesuai dengan jadwal yang lama atau berdasarkan jadwal yang sudah disusun sebelum pandemi Covid-19 mewabah di Indonesia tetapi porsi jam pelajarannya dikurangi, yang semula 1 jam pelajaran itu 45 menit maka diperpendek menjadi 1 jam pelajaran 30 menit. Jadwal belajar mengajar Ibuk Dra. Elmawati yaitu di kelas X IPS 1 setiap hari rabu di jam ke 3 dan hari kamis di jam ke 3-4, di kelas X IPS 2 setiap hari senin jam ke 2-3 dan hari rabu jam ke 4, di kelas X IPS 3 setiap hari senin di jam ke 6-7 dan hari rabu di jam ke 6, di kelas $\mathrm{X}$ IPS 4 setiap hari kamis jam ke 5 dan hari sabtu jam ke 2-3. Kemudian disetiap satu jam pelajaran Ibuk Dra. Elmawati tidak melakukan proses belajar mengajar dan hanya mengambil absensi siswa. Sedangkan untuk materi pembelajaran beliau berpedoman pada silabus yang sudah disiapkan sebelum pandemi Covid-19 tetapi kompetensi dasar dan indikator-indikator pembelajarannya di permudah yaitu pada minggu pertama materi pembelajaran yang dibahas adalah pengantar penelitian, minggu ke dua syarat-syarat penelitian, minggu ke tiga kegunaan penelitian, minggu ke empat tujuan penelitian dan pada minggu jenis-jenis penelitian.

Jurnal Sikola: Jurnal Kajian Pendidikan dan Pembelajaran Vol. 2, No. 1, Th. 2020 
Berbeda dengan proses pembelajaran yang dilakukan oleh Bapak Mhd Ulil Ikhsan, S.Sos di atas, pelaksanaan Student Centered Learning berbasis online learning yang dilakukan oleh Ibuk Dra Elmawati melalui grup WhatsApp sosiologi sudah terlaksana tetapi dalam setiap proses pembelajaran tidak terjadi diskusi dan tanya jawab. Karena beliau hanya memberi materi dan tugas kepada. Pemberian tugas ini membuat siswa mampu berfikir kritis. Kemudian setelah selesai tugas tersebut difoto dan dikirim ke grup WahtsApp sosiologi masing-masing kelas sesuai dengan waktu yang telah ditentukan.

Pada minggu pertama sampai minggu ke 5 beliau selalu melakukan pendahuluan pembelajaran selama 15 menit, hal yang biasa dilakukan oleh beliau, yaitu mengucapkan salam, kemudian beliau menanyakan kabar siswa, beliau juga menjelaskan bagaimana proses penilaian yang dilakukan dan setelah itu beliau meminta siswa mengisi absensi mata pelajaran sosiologi dan absensi sekolah, setelah itu beliau menyebutkan kompetensi dasar dan indikatorindikator yang akan dipelajari, kemudian beliau mengirimkan materi yang akan dipelajari pada setiap pertemuan ke WhatsApp group berupa foto power point dan foto bahan ajar yang berisi materi yang akan ditugaskan kepada siswa. Setelah itu pada kegiatan inti beliau meminta siswa untuk memahami bahan ajar yang telah diberikan selama 10 menit, kemudian guru memberikan tugas yang berkaitan denagan materi yang sudah dipahami tadi dan siswa mengerjakan tugas tersebut dalam buku catatan selama 30 menit. Setelah siswa menyelesaikan tugasnya, selama 5 menit pada kegiatan penutup guru meminta siswa untuk mengirim tugasnya ke WhatsApp group dalam bentuk foto dan setelah itu guru selalu memberikan pesan kepada siswa untuk tetap dirumah saja dan peduli akan kebersihan.

\section{Kendala-kendala dalam Pelaksanaan Student Centered Learning Berbasis Online Pembelajaran Sosiologi Siswa Kelas X IPS Masa Pandemi Covid-19.}

Berdasarkan wawancara yang telah peneliti lakukan dengan guru mata pelajaran sosiologi dan siswa-siswa kelas X IPS SMA Negeri 4 Bukittinggi ada kendala-kendala yang yang dirasakan oleh guru dan siswa dalam pembelajaran sosiologi adalah.

\section{Pengalokasian Waktu}

Pada proses pembelajaran daring waktu yang dirasakan guru dan siswa sedikit karena porsi jam pembelajaran diperpendek yang semula 1 jam pelajaran 45 menit menjadi 1 jam pelajaarn 30 menit. Kemudian waktu yang tersedia hanya 3 SKS dan guru harus melakukan proses pembelajaran selama 3 SKS tersebut secara daring. Karena interaksi antara guru dan siswa tidak terjadi secara langsung dan sistem sekolah formal, maka terkadang waktu jam belajar ini molor. Dimana lamanya waktu untuk absensi yang dilakukan oleh siswa, kemudian guru susah mengkondisikan siswa untuk masuk kelas tepat pada waktunya dimana guru tidak tau kapan siswa masuk kelas, apakah siswa masuk kelas. hal ini terjadi karena proses pembelajaran hanya menggunakan WhatsApp group.

Karena pembelajaran dilakukan secara daring melalui WhatsApp group, sehingga penerapan student centered learning ini agak susah terutama mengatur waktu jam pelajaran dan absensi. Mulai jam pelajarannya sering molor, tugas tidak bisa diatur, kapan siswa mengumpulkan tugas dan berapa lama siswa mengumpulkannya. Sehingga proses pembelajaran tidak efektif, tidak semua materi pembelajaran bisa di diskusikan dalam satu waktu dan akhirnya membuat siswa tidak paham dengan materi yang sedang dipelajari. Kemudian proses pembelajaran Student Centered Learning dengan menggunakan discovery learning membutuhkan waktu yang tidak sebentar yang mana dalam proses pembelajaran guru melakukan pendahuluan dengan mengucapkan salam, menanyakan kbar siswa, mengambil absensi, menyebutkan materi yang akan dipelajari. Setelah itu pada kegiatan inti proses pembelajaran yang dilakukan adalah diskusi tanya jawab yang menuntut siswa harus berfikir kritis dan aktif. Selama diskusi berlangsung guru memberikan pertanyan-pertanyaan mengenai

Jurnal Sikola: Jurnal Kajian Pendidikan dan Pembelajaran Vol. 2, No. 1, Th. 2020 
materi pembeljaran dan siswa mencari jawabannya, sehingga siswa membutuhkan waktu untuk mencari jawabannya tersebut. Apalagi jika ada siswa yang tidak mengerti dengan pembelajaran maka guru harus menjelaskan kepada siswa agar tujuan pembelajaran tercapai. Terakhir pada kegiatan penutup guru dan siswa menyimpulkan pembelajaran yang sudah dibahas, kemudian guru memberikan masukan-masukan kepda siswa mengenai pembelajaran dan guru memberikan tugas kepa siswa, sehingga dalam kegiatan penutup ini juga membutuhkan waktu.

\section{Kemampuan Guru Sosiologi Menggunakan Teknologi Informasi Terbatas}

Pada masa pandemi Covid-19 ini proses pembelajaran dilakukan secara daring dengan memanfaatkan berbagai teknologi yang bisa dipakai oleh guru dan siswa selama pandemi Covid-19. Teknologi yang bisa digunakan selama pandemi Covid-19, yaitu aplikasi WhatsApp, Google Classroom, Zoom, Telegram, Email, Telegram, Link Web yang disediakan oleh sekolah. Meskipun begitu, guru sosiologi di SMA Negeri 4 Bukittinggi hanya menggunakan WhatsApp group dalam proses pembelajaran. Berdasarkan wawancara yang peneliti lakukan dengan Bapak Mhd Ulil Ikhsan, S.Sos dan Ibuk Dra. Elmawati, beliau hanya mengguanakan WahatsApp group dalam melaksanakn proses pembelajaran. Hal ini disebabkan karena guru sosiologi tersebut belum bisa menggunakan aplikasi pembelajaran lain dan menurut beliau aplikasi WhatsApp mudah digunakan dan sudah biasa digunakan baik guru maupun siswa. Jadi dapat peneliti simpulkan bahwa Student Centered Learning bisa dilaksanakan tapi tdak efektif dengan mnggunakan WhatsApp group saja, seharusnya guru juga harus menggunakan aplikasi lain, seperti Google Classroom, Zoom, Telegram, Email, Telegram, Link Web yang disediakan oleh sekolah. Sehingga proses pembelajaran dapat berlangsung lebih baik.

\section{Penerapan SCL dalam kajian Teori Struktural Fungsional}

Permasalahan tersebut dapat dianalisis dengan teori struktural fungsional dari Talcot Parsons. Menurut teori ini masyarakat merupakan suatu sistem sosial yang terdiri atas bagianbagian atau elemen yang saling berkaitanan saling menyatu dalam keseimbangan. Perubahan yang terjadi pada suatu bagian akan membawa perubahan pula terhadap bagian yang lain. Menurut Parson untuk mewujudkan suatu masyarakat yang tertib dan teratur dapat dilakukan dengantindakan yang dikenal dengan skema AGIL (Adaption, Goal Attainment, Integratin dan Latency).

\section{Adaptation (Adaptasi)}

Adaptation atau Adaptasi adalah suatu sistem yang harus menanggulangi situasi eksternal yang gawat. Sistem harus menyesuaikan diri dengan lingkungan dan menyesuaikan lingkungan itu dengan kebutuhannya. Sejak diberlakukannya kurikulum 2013 di SMA Negeri 4 Bukittinggi yang mana kurikulum tersebut menuntut kektifan siswa atau dikenal dengan pembelajaran student centered learning maka guru dan siswa harus mampu menyesuaikan diri dengan kurilum tersebut. Terutama dalam pembelajaran sosiologi yang berorientasi pada pemecahan masalah dan pemberdayaan sosial.

Sejak dikeluarkannya Surat Edaran No 4 Tahun 2020 tentang pelaksanaan kebijakan pendidikan dalam masa darurat penyebaran coronavirus disease (COVID-19) oleh Menteri Pendidikan dan Kebudayaan Republik Indonesia, SMA Negeri 4 Bukittinggi mengeluarkan kebijakan untuk melakukan proses belajar mengajar secara online. Oleh sebab itu, guru dan siswa harus mampu menyesuaikan diri dengan proses pembelajaran online terebut. Proses pembelajaran yang digunakan di SMA Negeri 4 Bukittinggi adalah WhatsApp, Google Classroom, Zoom, Telegram, Email, Telegram, Link Web yang disediakan oleh sekolah. Oleh karena itu guru harus mampu menggunakan berbagai aplikasi terutama dalam pembelajaran sosiologi yang menuntut keaktifan serta kemampuan siswa untuk berfikir kritis. 


\section{Goal Attainment (pencapaian tujuan)}

Goal Attainment atau pencapaian tujuan adalah sebuah sistem harus mendefenisikan dan mencapai tujuan utamanya. Setiap tindaka manusia selalu mempunyai tujuan tertentu. Akan tetapi tujuan individu seringkali bertentangan dengan tujuan-tujuan lingkungan sosial yang lebih besar dari sekedar kepentingan individu. Karena seseorang harus hidup dalam suatu sitem sosial maka untuk mencapai kepentingan individu harus menyesuaikan diri dengan kepentingan yang lebih besar yaitu kelompok.

Tujuan sekolah menerapkan kurikulum 2013 yang berbasis student centered learning dalam proses pembelajaran adalah agar siswa mampu berfikir kritis, aktif dan mandiri dalam proses pembelajaran terutama pada pembelajaran sosiologi. Sehingga nanti tercapai tujuan pembelajaran sosiologi yang dituntut dalam kurikulum 2013. Kemudian tujuan sekolah mengeluarkan kebijakan untuk melakukan pembelajaran online dalam proses belajar mengajar adalah agar Covid-19 tidak menyebar secara cepat.

\section{Integration (integrasi)}

Integration atau integrasi adalah sebuah sistem harus mengatur hubungan antar bagian bagian yang menjadi komponennya. Sistem juga harus mengelola antarhubungan ketiga fungsi penting lainnya $(A, G, L)$. konsep integrasi menunjukkan adanya bagian dari solidaritas sosial yang membentuk serta berperannya masing-masing unsure tersebut sesuai dengan posisi dan statusnya. Ikatan solidaritas akan menjadi berantakan apabila masing-masing unsure yang membentuk suatu sistem itu memperlihatkan atau mengedepankan kepentingan masingmasing.

Penerapan kurikulum 2013 dengan pembelajaran student centered learning terutama dalam pembelajaran sosiologi di SMA Negeri 4 Bukittinggi bertujuan agar siswa mampu berfikir kritis, aktif, dan mandiri sehingga nantinya akan melahirkan orang-orang yang dapat bersosialisasi dengan baik, terampil dan berwawasan luas dalam lingkungan masyarakat. Selain itu, sekolah juga memberlakukan pembelajaran online, agar guru dan siswa dapat melakukan pembelajaran dari rumah sehingga akan mengurangi penyebaran wabah Covid-19 di lingkungan masyarakat.

\section{Latency (pemeliharaan Pola)}

Latency atau pemeliharaan pola adalah sebuah sistem harus melengkapi, memelihara, dan memperbaiki baik motivasi individu maupun pola - pola cultural yang menciptakan dan menopang motivasi. Pihak sekolah dan siswa sama-sama menjalankan proses pembelajaran berdasarkan pembelajaran yang telah ditetapkan. Agar tidak adanya kesalahan-kesalahan maupun kekeliruan dalam pelaksanaan pembelajaran maka pihak sekolah harus memberikan arahan-arahan kepada guru dan siswa agar tujuan pembelajaran dapat tercapai (Ritzer, 2014).

\section{Kesimpulan}

Berdasarkan hasil penelitian yang telah peneliti lakukan dapat disimpulkan bahwasanya pelaksanaan Student Centered Learning berbasis online learning bisa dilaksanakan melalui teknologi informasi WhatsApp group di SMA Negeri 4 Bukittinggi. Hal ini terlihat dari proses pembelajaran yang dijalankan menuntut keaktifan siswa selama proses dan menuntut siswa harus berfikir kritis dalam mencari jawabanya dari tugas yang diberikan oleh guru. Adapun Kendala-kendala yang dirasakan oleh guru dan siswa selama pelaksanaan Student Centered Learning berbasis online learning pada pembelajaran Sosiologi siswa kelas X IPS SMA Negeri 4 Bukittinggi masa pandemi Covid-19, yaitu: Pertama, pada proses pembelajaran daring waktu yang dirasakan guru dan siswa sedikit karena porsi jam pembelajaran diperpendek yang semula 1 jam pelajaran 45 menit menjadi 1 jam pelajaarn 30 menit. Kemudian waktu yang tersedia hanya 3 SKS dan guru harus melakukan proses pembelajaran selama 3 SKS tersebut secara daring. Karena interaksi antara guru dan siswa tidak terjadi secara langsung dan sistem sekolah

Jurnal Sikola: Jurnal Kajian Pendidikan dan Pembelajaran Vol. 2, No. 1, Th. 2020 
formal, maka terkadang waktu jam belajar ini molor. Dimana lamanya waktu untuk absensi yang dilakukan oleh siswa, kemudian guru susah mengkondisikan siswa untuk masuk kelas tepat pada waktunya dimana guru tidak tau kapan siswa masuk kelas, apakah siswa masuk kelas. hal ini terjadi karena proses pembelajaran hanya menggunakan WhatsApp group. Karena pembelajaran dilakukan secara daring melalui WhatsApp group, sehingga penerapan student centered learning ini agak susah terutama mengatur waktu jam pelajaran dan absensi . mulai jam pelajarannya sering molor, tugas tidak bisa diatur, kapan siswa mengumpulkan tugas dan berapa lama siswa mengumpulkannya. Sehingga proses pembelajaran tidak efektif, tidak semua materi pembelajaran bisa di diskusikan dalam satu waktu dan akhirnya membuat siswa tidak paham dengan materi yang sedang dipelajari. Kemudian proses pembelajaran Student Centered Learning dengan menggunakan discovery learning membutuhkan waktu yang tidak sebentar yang mana dalam proses pembelajaran guru melakukan pendahuluan dengan mengucapkan salam, menanyakan kbar siswa, mengambil absensi, menyebutkan materi yang akan dipelajari. Setelah itu pada kegiatan inti proses pembelajaran yang dilakukan adalah diskusi tanya jawab yang menuntut siswa harus berfikir kritis dan aktif. Selama diskusi berlangsung guru memberikan pertanyan-pertanyaan mengenai materi pembeljaran dan siswa mencari jawabannya, sehingga siswa membutuhkan waktu untuk mencari jawabannya tersebut. Apalagi jika ada siswa yang tidak mengerti dengan pembelajaran maka guru harus menjelaskan kepada siswa agar tujuan pembelajaran tercapai. Terakhir pada kegiatan penutup guru dan siswa menyimpulkan pembelajaran yang sudah dibahas, kemudian guru memberikan masukan-masukan kepda siswa mengenai pembelajaran dan guru memberikan tugas kepa siswa, sehingga dalam kegiatan penutup ini juga membutuhkan waktu. Kedua, pada masa pandemi Covid-19 ini proses pembelajaran dilakukan secara daring dengan memanfaatkan berbagai teknologi yang bisa dipakai oleh guru dan siswa selama pandemi Covid-19. Teknologi yang bisa digunakan selama pandemi Covid-19, yaitu aplikasi WhatsApp, Google Classroom, Zoom, Telegram, Email, Telegram, Link Web yang disediakan oleh sekolah. Meskipun begitu, guru sosiologi di SMA Negeri 4 Bukittinggi hanya menggunakan WhatsApp group dalam proses pembelajaran. Berdasarkan wawancara yang peneliti lakukan dengan Bapak Mhd Ulil Ikhsan, S.Sos dan Ibuk Dra. Elmawati, beliau hanya mengguanakan WahatsApp group dalam melaksanakn proses pembelajaran. Hal ini disebabkan karena guru sosiologi tersebut belum bisa menggunakan aplikasi pembelajaran lain dan menurut beliau aplikasi WhatsApp mudah digunakan dan sudah biasa digunakan baik guru maupun siswa. Selanjutnya teori yang digunakan dalam penelitian ini adalah teori struktural fungsional "AGIL" yang dikemukan oleh Talcott Parson.

\section{Daftar Pustaka}

Adji, N. (2020). Bahasa Indonesia di Belantara Istilah Asing Terkait Covid-19. www.kompas.id. https://bebas.kompas.id/baca/opini/2020/04/11/bahasa-indonesia-di-belantara-istilahasing-terkait-covid-19/

Clorawati, A. R., Rohiat, S., \& Amir, H. (2017). Implementasi kurikulum 2013 bagi guru kimia. Jurnal Pendidikan dan Ilmu Kimia, 1(2), 132-135.

Depdiknas. (2003). Undang-Undang Republik Indonesia Nomor 20 Tahun 2003 Tentang Sistem Pendidikan Nasional. http://simkeu.kemdikbud.go.id/index.php/peraturan1/8-uuundang-undang/12-uu-no-20-tahun-2003-tentang-sistem-pendidikan-nasional

Fernandes, R. (2017). Adaptasi Sekolah terhadap Kebijakan Pendidikan Inklusif. Jurnal Socius: Journal of Sociology Research and Education, 4(2), 119-125. https://doi.org/10.24036/ scs.v4i2.16

Fernandes, R. (2019). Relevansi Kurikulum 2013 dengan Kebutuhan Peserta Didik di Era Revolusi 4.0. Jurnal Socius: Journal of Sociology Research and Education, 6(2), 70-89.

Gugus Tugas Percepatan Penanganan COVID-19. (2020). Infografis COVID-19 (30 Juni 2020). www.covid19.go.id. https://covid19.go.id/p/berita/infografis-covid-19-30-juni-2020

Jurnal Sikola: Jurnal Kajian Pendidikan dan Pembelajaran Vol. 2, No. 1, Th. 2020 
Herliandry, L. D., Nurhasanah, Suban, M. E., \& Kuswanto, H. (2020). Pembelajaran Pada Masa Pandemi Covid-19. Jurnal Teknologi Pendidikan, 22(1), 65-70.

Hosnan. (2014). Pendekatan Saintifik dan Kontekstual dalam Pembelajaran Abad 21: Kunci Sukses Implementasi Kurikulum 2013. Bogor: Ghalia Indonesia.

Kemendikbud RI. (2020). Surat Edaran Nomor 4 Tahun 2020 Tentang Pelaksanaan Kebijakan Pendidikan Dalam Masa Darurat Penyebaran Coronavirus Disease (Covid- 19).

Marharjono. (2020). Manfaat Pembelajaran Sejarah Menggunakan Google Classroom Pada Masa Pandemi Covid-19. Jurnal Karya Ilmiah Guru, 5(1), 56-63.

Mutmainah, E., \& Pratiwi, poerwanti hadi. (2019). Implementasi Pembelajaran Sosiologi Dalam Konteks Kurikulum 2013. E-Societas, 8(5), 2-15.

Prasetyo, Z. K. (2017). Pembelajaran dan Kompetensi Pendidik Abad-21. Prosiding Seminar Nasional Inovasi Pendidikan. Universitas Negeri Sebelas Maret.

Purwanto, A., Pramono, R., Asbari, M., Santoso, P. B., Wijayanti, L. M., Hyun, C. C., \& Putri, R. S. (2020). Studi Eksploratif Dampak Pandemi COVID-19 Terhadap Proses Pembelajaran Online di Sekolah Dasar. Journal of Education, Psychology and Counseling, 2(1), $1-12$.

Putra, D.M, \& Nurlizawati, N. (2019). Lesson Study dalam Meningkatkan Ketrampilan 4C (Critical Thingking, Collaborative, Communicative dan Creative) pada Pembelajaran Sosiologi yang Terintegrasi ABS-SBK di SMAN 1 Pasaman. Jurnal Sikola: Jurnal Kajian Pendidikan dan Pembelajaran, 1(2), 139-146. https://doi.org/10.24036/sikola.v1i2.19

Rahardjo, Susilo, \& Gudnanto. (2011). Pemaahan Individu Teknik Non Tes. Kudus: Nora Media Enterprise.

Ritzer, G. (2014). Teori Sosiologi Modern. Edisi ke-7. Jakarta: Kencana.

Rusman,R. (2014). Model-Model Pembelajaran. Jakarta: Rajawali Persada.

Soekanto, S. (2012). Sosiologi Suatu Pengantar. Jakarta: Rajawali Pers.

Sukmadinata, \& Nana, S. (2007). Metode Penelitian Pendidikan. Bandung: PT. Remaja Rosdakarya.

Syahputra, E. (2018). Pembelajaran Abad 21 dan Penerapannya di Indonesia. Prosiding Seminar Nasional SINASTEKMAPAN. Universitas Negeri Medan.

Sylvia, I., Anwar, S., \& Khairani, K. (2019). Pengembangan Instrumen Penilaian Autentik Berbasis Pendekatan Authentic Inquiry Learning Pada Mata Pelajaran Sosiologi di Sekolah Menengah Atas. Socius, 6(2), 103. https://doi.org/10.24036/scs.v6i2.162

Wijaya, E \& Nyoto, A. (2016). Transformasi Pendidikan Abad 21 Sebagai Tuntutan Pengembangan Sumber Daya Manusia di Era Global. Prosiding Seminar Nasional Pendidikan Matematika. Universitas Kanjuruhan Malang.

Yusuf, A. M. (2014). Metode Penelitian Kuantitatif, Kualitatif \& Penelitian Gabungan. Jakarta: Kencana. 